\title{
PEDAGOGICAL POTENTIAL \\ FOR PROFESSIONAL PREPARATION OF MASTERS
}

\section{ПЕДАГОГІЧНИЙ ПОТЕНЦІАЛ \\ ПРОФЕСІЙНОЇ ПІДГОТОВКИ МАГІСТРАНТІВ}

\author{
Smolinska Olesia ${ }^{1}$ \\ Machynska Nataliya ${ }^{2}$ \\ DOI: http://dx.doi.org/10.30525/978-9934-571-27-5_49
}

\begin{abstract}
The paper deals with the actual theme of formation of pedagogical potential in the professional training of masters. To achieve the goal, which consisted in the analysis of the peculiarities of the development and formation of the pedagogical potential of masters of various educational programs of training, and a number of tasks were formed. There were key among them: the choice of the approach to the concept content "pedagogical potential", the definition of types of professional and pedagogical preparation of masters and the characteristics of the corresponding methods of formation of pedagogical potential. The methodological basis for the search of the pedagogical potential of professional training for masters is the general ontology of system-structural analysis, the theory of activity, the theory of intellection, the theory of science and semiotics. The research is based on the general scientific methodology, provides use as theoretical (analysis, synthesis, generalization, inferences, typology), and practical methods (questionnaires).

Through the analysis of scientific literature, as most appropriate to the goals and objectives, the following definition was adopted: "The teacher's professional pedagogical potential is a complex dynamic personal education that integrates a set of internal personal resources of a person (psycho-physiological properties, needs, abilities, value orientations, settings, personal qualities, motives, knowledge, skills, etc.), which, under certain external conditions, may occur in professional activities in the form of con-

\footnotetext{
${ }^{1}$ Doctor of Pedagogical Science, Associate Professor, Head of the Department of Philosophy and Pedagogy,

Stepan Gzhytskyi National University of Veterinary Medicine and Biotechnologies Lviv, Ukraine ${ }^{2}$ Doctor of Pedagogical Science, Associate Professor, Head of the Department of Preschool and Primary Education, Ivan Franko National University of Lviv, Ukraine
} 


\section{Pedagogical potential for professional preparation of masters}

scious professional actions in situations of professional choice (Rasskazov, Katerbarg, 2013)".

Due to the analysis of the relevant documents, it is determined, that in Ukraine there are three types of professional-pedagogical training: point, binary (double, parallel) and linear. Each of these types is found at the master's level, but only the point does not apply to the baccalaureate. Each of these types is characterized by the positions of solvable problems and the corresponding way of becoming / development of pedagogical potential. The point type is aimed at propaedeutic preparation for the possible implementation by graduates of the magistracy of pedagogical activity, the method of influence on pedagogical potential is defined as diffuse, which does not provide system training, but provides a ground for further self-development as a teacher. The binary type is oriented both to the bachelor's degree and to the master's degree. Its task is systematic professionally and pedagogical training, closely linked with other professional education and activities. The method of forming a pedagogical potential for this type is deductive, since in this case the system basis provides the formation of individual pedagogical stylistics and skill. The third, linear, type is organisationally the most traditional, since it is represented by a two-level system of professional and pedagogical training, which implements the classical organizational principles of continuity, consistency, and systemicity. The method which is the most appropriate for this type of development of pedagogical potential is inductive, since (by analogy with the inference) methodologically ensures the formation of a professional person, organic fusion of personal and professional features.

In the context of the spatial-environmental approach, attention was paid to the development of the teacher's capacity of higher education in general and graduation department in particular. The role of the latter both in the formation of the educational program and in its implementation by the masters is the leading one.

\section{1. Ветуп}

Проблема ефективності освітньої / педагогічної діяльності є складною насамперед через всеохопність критеріїв визначення результативності. Автори проекту концепції розвитку педагогічної освіти (2017) означують це як «багатогранність, яка у своїх вищих проявах підіймається до мистецтва» $[10$, с. 2$]$, зазначаючи також, що «високий рівень академічних досягнень, продемонстрований здобувачем педагогічного 
фаху під час навчання у закладі освіти, не гарантує його успішності в професійній діяльності» [10, с. 2]. Таким чином, названа проблема розгалужується на результативність професійно-педагогічної підготовки в розрізі співвіднесення докладених зусиль як зі сторони ЗВО, так і здобувача вищої освіти. У робочих документах ЮНЕСКО, присвячених педагогіці XXI століття, зазначено, що «головною ціллю освіти 21 століття є створення навчальних можливостей для індивідуальності, підтримка ï розвитку протягом життя, активність, незалежність учнів, за яких вчителі повинні стати «тренерами з навчання» - роль, дуже відмінна від традиційного вчителя класу» [22, с. 14]. 3 цим же пов'язаний як механізм результативності (відхід від концепції наслідування як провідної в учінні), так і результат, що перетворюється 3 рівневого (кількісного) на індивідуальний (якісний). Його можна означити як додану освітню вартість, що має як одиничне, так і сумарно-синергічне вираження (нарощення потенціалу).

Отже, актуальність дослідження педагогічного потенціалу як освітньої передумови та освітнього результату в умовах магістратури педагогічних спеціальностей зумовлена оновленням загальних підходів до освіти як ландшафту, iіi результативності у вимірі індивіда - як численних переходів від його ролі ланки в ланцюгу до творця ланцюжків доданої вартості [20, с. 15].

Мета публікації - проаналізувати фактори формування та розвитку педагогічного потенціалу магістрантів різних освітніх програм підготовки.

Для досягнення мети плануємо розв'язати такі завдання:

- визначити та співставити змістове наповнення поняття «педагогічний потенціал»;

- проаналізувати освітні програм підготовки магістрантів за різними спеціальностями;

- типологізувати професійно-педагогічну підготовку магістрантів 3 позицій формування педагогічного потенціалу;

- охарактеризувати способи становлення педагогічного потенціалу відповідно до типу професійно-педагогічної підготовки.

Методологічним базисом дослідження педагогічного потенціалу професійної підготовки магістрантів є загальна онтологія системно-структурного аналізу, теорія діяльності, теорія мислення, теорія науки та семіотика. 


\section{Pedagogical potential for professional preparation of masters}

Логіка подання дослідженого матеріалу полягає у вивченні підходів до тлумачення категорії та означення поняття «педагогічного потенціалу», визначенні й аналізі типів професійно-педагогічної підготовки магістрів, розкритті специфіки наскрізної підготовки магістрів та магістратури на основі перехресного вступу, узагальненні способів формування педагогічного потенціалу професійної підготовки магістрів.

\section{2. Підходи в дослідженнях концепту педагогічного потенціалу}

Вивчення вітчизняних літературних джерел засвідчує, що концепт педагогічного потенціалу часто виконує допоміжну функцію в характеристиках форм, видів, методів освітньої / педагогічної діяльності. Так, наприклад, зараз активно досліджується проблематика педагогічного потенціалу мистецької [3; 16], дозвіллєвої [5; 21], спортивно-оздоровчої [26] діяльності; освітніх технологій [7; 13]; професій та релігій [15; 27], дидактичних засобів [25]. Існує низка публікацій з управління, які тлумачать педагогічний потенціал як відповідність кадрової структури завданням управління закладом. Перелічені вище джерела $\epsilon$, радше, ілюстративними, ніж аналітичними щодо нашої теми.

Якщо аналізувати наукову літературу близького зарубіжжя, то можна виявити дещо іншу тенденцію. Це, насамперед, увага дослідників до педагогічного потенціалу особистості вчителя. Переважна більшість досліджених нами публікацій $[4 ; 6 ; 17]$ за вихідну точку беруть дослідження О.М. Боднаря, яким і запроваджено цей підхід, а категорія педагогічного потенціалу змістово корелює із особистим, оскільки означується як складне комплексне поняття, здібності та синтез певних особистісних якостей та властивостей людини, що забезпечують ефективність педагогічної діяльності [1]. Цей підхід наближає нас до вирішення поставлених завдань, проте вважаємо, що найбільш прийнятним буде визначення, доповнене вчинковим підходом: «Професійний педагогічний потенціал педагога - це складне динамічне особистісне утворення, що інтегрує сукупність внутрішніх особистих ресурсів людини (психофізіологічні властивості, потреби, здібності, ціннісні орієнтації, установки, особисті якості, мотиви, знання, уміння, навички та ін.), які за певних зовнішніх умов можуть проявитися у професійній діяльності у формі усвідомлених професійних дій в ситуаціях професійного вибору» [17, с. 139]. Крім того, виходитимемо із тези, що «що кожен студент є потенційним носієм педагогічної 
сутності» [2], доповнивши ії суб’єктно: «А також вчитель, викладач, заклад вищої освіти». Характеристично, педагогічна сутність є творчо-інноваційною, оскільки, закладаючись у процесі педагогічної підготовки, «реалізується у процесі педагогічної творчості» [19].

\section{3. Типологія професійно-педагогічної підготовки}

Відповідно до сучасної системи професійної підготовки можна виокремити такі типи професійно-педагогічної підготовки.

Перший, точковий, тип. Згідно з ним всі магістранти різних спеціальностей вивчають одну (рідше - дві) навчальні дисципліни пропедевтичного характеру, завданням якої / яких є підготувати грунт для можливого переходу від рівня повсякденного стороннього спостереження професійних аспектів педагогічної діяльності до рівня їх осмислення. 3 цієї метою в навчальні плани зазвичай включаються такі дисципліни, як педагогіка і психологія вищої школи, методика викладання у вищій школі, крім того, елементом практичного навчання є асистентська практика, що, в рамках цього типу, часто є складовою інших видів практик.

Другий, бінарний (подвійний, рівнобіжний), тип, хоч більше властивий бакалаврському рівню, проте є якісною передумовою формування педагогічного потенціалу в магістратурі. Згідно з В.А. Козаковим [9] це шлях поступового формування педагогічного потенціалу студента, який обрав непедагогічну спеціальність (найчастіше - в університеті непедагогічного профілю). Саме $з$ ініціативи цього науковця до освітньо-професійної програми підготовки, щоправда, бакалавра галузі знань «Економіка і підприємництво» (згідно із класифікацією 2010 року) було включено блок вибіркових дисциплін психолого-педагогічної підготовки, зокрема «Психологія діяльності та навчальний менеджмент», «Комунікативні процеси у навчанні» та «Методика викладання економіки» [14]. Їх засвоєння передбачало поступове формування професійно орієнтованих рис не лише як економістів, маркетологів, але й як викладачів. При цьому класична педагогічна підготовка не провадилась.

Ще одним варіантом другого типу є навчання за спеціальністю 015 «Професійна освіта (за спеціалізаціями)», теж бакалаврський рівень, яке, часто, здійснюється в руслі додаткової спеціальності. Цей тип підготовки охоплює широкий спектр педагогічної проблематики. Контент-аналіз наявної на сайтах закладів вищої освіти інформації про навчальні плани засвідчує, що перелік дисциплін формується 3 
урахуванням уже наявного педагогічного (у значенні кадрово-викладацького) потенціалу.

Наступним варіантом бінарного типу $є$ підготовка магістрів за спеціальністю 011 «Освітні, педагогічні науки», що здійснюється для випускників не нижче першого (бакалаврського) рівня.

Третій, лінійний, тип стосується питомо педагогічної магістратури на основі попередньо здобутої педагогічної спеціальності.

У публікації розглянемо особливості другого і третього типів професійної підготовки магістрів. У контексті педагогічного потенціалу їх об'єднує необхідність урахування особливостей культурно-освітнього простору конкретного закладу вищої освіти, в якому відбувається циркулювання професійних та педагогічних цінностей і традицій. Зокрема його варіантами можуть бути культурно-освітній простір педагогічного, класичного чи непрофільного ЗВО. Це впливатиме на зміст навчальних планів, що більш наочно видно на етапі бакалаврської підготовки. Наприклад, аналіз навчальних планів спеціальності 6.010101 «Дошкільна освіта» (2013-2014 рр., до відміни стандартів) засвідчує наявність таких відмінностей:

- університетські наукові школи, що існували чи склалися впродовж останніх 20 років (ПНУ імені Василя Стефаника - етнопедагогіки та історія педагогіки; ЛНУ імені Івана Франка - опертя на наявні філологічну, правничу та інші школи, дДПУ імені Івана Франка - на провідну націознавчу та соціально-гуманітарну тематику);

- регіональні відмінності (вони не суттєві в межах університетів Західного регіону України, проте аналогічне дослідження із включенням педагогічних університетів 3 інших регіонів України їх виявить, що випливає з помічених у процесі обробки особливостей подачі відомостей про історію університетів, ступінь осмислення власної ідентичності та відповідних проекцій у навчальних планах; наприклад, за напрямом 6.010101 «Дошкільна освіта» ПНУ імені Василя Стефаника пропонує на вибір навчальну дисципліну «Історія освіти Прикарпаття», ЛНУ імені Івана Франка - «Історія Львівського університету», ДДПУ імені Івана Франка - «Історія ОУН і УПА», «Історія українського війська», «Поезія Тараса Шевченка», «Етногеографія України», «Історія української діаспори», «Україна в Свропі і світі»)» [24, с. 379].

Зараз на навчальні плани магістрантів впливає як науковий потенціал випускної кафедри, так і характеристики культурно-освітнього простору 
закладу вищої освіти в цілому. Ключовими механізмами цього процесу є становлення суб'єктності й об'єктивація. Ці два процеси інтегровані між собою. Перший передбачає розширення рамок суб'єктності в освіті, що відповідає Закону України «Про вищу освіту», який надає статусу елементів системи не лише учасникам освітнього процесу та органам управління, а й закладам вищої освіти, рівням та ступеням вищої освіти, галузям знань і спеціальностям, освітнім та науковим програмам, стандартам освітньої діяльності та стандартам вищої освіти [8, ст. 11]. Таким чином професіоналізм, отже, й педагогічний потенціал, формується та розвивається під впливом низки чинників-суб'єктів різного типу. Другий процес, об'єктивація, що є перетворенням «суб'єктивного змісту свідомості в самостійну, незалежну від свідомості сутність» [23, с. 495], одночасно є як наслідком суб'єктивації (в руслі цього визначення змістом [колективної] свідомості), так і її обставиною. Щодо предмету нашого дослідження, педагогічного потенціалу, ці процеси діють одночасно, хоч і не односпрямовано: суб' єктивація $є$ накопиченням потенціалу, тоді як об'єктивація визначає його якість.

Отже, становлення і розвиток педагогічного потенціалу відбувається у ході професійно-педагогічної підготовки, що проходить в обставинах різних освітніх програм, культурно-освітніх просторів, суб'єктів (рис. 1).

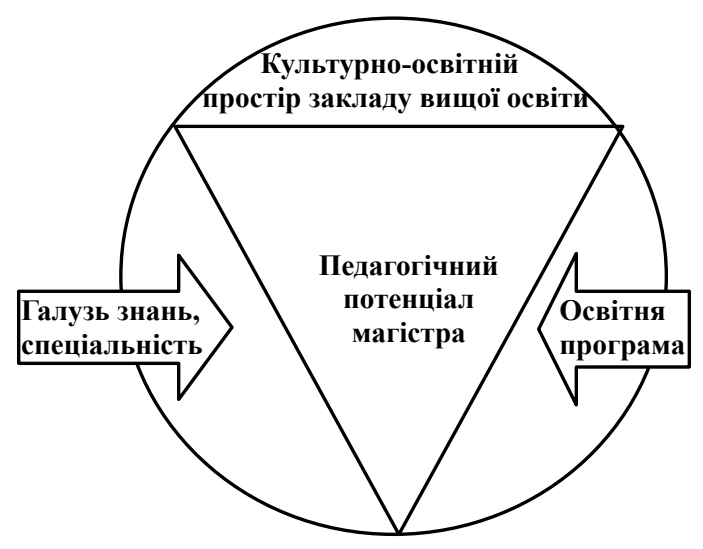

Рис. 1. Чинники впливу на педагогічний потенціал магістрів (складено авторами самостійно) 


\section{Pedagogical potential for professional preparation of masters}

На рис. 1 зображені тільки абстрактні чинники, що впливають на формування і розвиток педагогічного потенціалу магістрів у їх професійній підготовці. Суб'єктні чинники (заклад вищої освіти, кафедра, кадровий склад, магістранти) не зображені, оскільки вони, упереваж, мають конкретний характер, тому погано піддаються узагальненню та схематизації.

\section{4. Формування педагогічного потенціалу магістрантів,} які не мають бакалаврського ступеня 3 педагогіки

Якщо характеризувати додану освітню вартість (забезпечення прирощення/формування педагогічного потенціалу), що повинна сформуватися завдяки навчанню в магістратурі неспоріднених спеціальностей, то вона мала б мати достатньо високі показники бодай за рахунок того, що різниця вхідного та вихідного професійно-педагогічного потенціалу є значною через низький показник вхідного. Не вважаємо його нульовим на основі того, що для вступу в магістратуру абітурієнт повинен скласти два вступні фахові іспити, це засвідчує його теоретичну підготовленість. Крім того, навчальний досвід вступника на момент початку магістратури складає не менше 15 років (школа, бакалаврат). Оскільки навчальна діяльність є складною i, щонайменше, двокомпонентною, а провідним механізмом учіння, поки що, залишається наслідування, можна говорити і про загальну сформованість та усталеність загального образу педагогічної діяльності.

В аспекті педагогічного потенціалу викладачів непрофільних закладів вищої освіти існує загальна проблема ідентифікаційного характеру, що, з початком навчання в педагогічній магістратурі, конкретизується і в студентів. Експрес-опитування, проведене серед досвідчених співробітників кафедр непедагогічних спеціальностей у непрофільному 3ВО виявило таку тенденцію: опитані науково-педагогічні працівники університету на питання «Ваша актуальна професія. Я зараз - ...», - відповіли назвавши свій фах за дипломом у 28,6 \% випадків, інші дали відповіді, з яких слідує, що актуальною для них професією є викладацька (при цьому як уточнення були вказані різні iii аспекти: педагогічний, науковий, управлінський). Їх стаж роботи у ЗВО становив, у середньому, 25 років. Це, на нашу думку, свідчить про наявну амбівалентність професійних цінностей, що є природною для культурно-освітнього простору галузевого університету. Водно- 
час, здійснюючи підготовку магістрів педагогіки за бінарним типом, слід тримати в полі зору проблему поєднання різних професійних цінностей, де одним із етапів формування комбінації «цінності професії - педагогічні цінності» $\mathrm{e}$ «відкриття» суті проблеми та формулювання цілей і завдань з її розв'язання.

Для подолання цього ідентифікаційного розриву магістрантам спеціальності 011 «Освітні, педагогічні науки» Львівського національного університету ветеринарної медицини та біотехнологій імені С.3. Гжицького запропоновані дисципліни «Університетська освіта», «Імідж сучасного педагога», «Комунікативні процеси у навчанні», «Педагогічна етика та деонтологія», до програми «Педагогіка вищої освіти» включений блок тем з історії педагогіки. У зв'язку із цим набуває особливої ваги організація педагогічного супроводу практик та специфіка керівництва курсовими і магістерськими роботами, що, на нашу думку, разом із поточною студентською науковою роботою в гуртках, повинні складати тематично цілісний етап професійно-педагогічного становлення.

Іншим аспектом, що потребує особливої уваги через попередній освітній досвід, є подолання впливовості (як позитивної, так і негативної) референтних осіб з числа викладачів дисциплін професійної спрямованості, таким чином - забезпечення можливості формування випускниками магістратури власної стилістики педагогічної діяльності. В аспекті продовження аналізу навчального плану - це дисципліни професійної та практичної підготовки «Педагогічна риторика», «Сучасні технології викладання», «Інформаційно-комунікаційні технології в освіті». Індивідуальний підхід у формуванні педагогічного потенціалу забезпечує безпосередня участь магістрантів у якомога більшій кількості науково-педагогічних заходів (в тому числі - в роботі науково-методичного семінару кафедри). Таким способом наявні шаблони педагогічної діяльності у професії втрачають стійкість, що сприяє вивільненню особистого творчо-інноваційного потенціалу магістранта.

Отже, одним з аспектів професійно-педагогічної підготовки магістрів за бінарним типом $€$ ïi опосередкованість попередньою спеціальністю. Через це виникають певні обмеження впливовості випускної кафедри (діють попередні професійні якорі). Ефективними способами ïx подолання є поширення сучасної педагогічної інформації шляхом 
організації та проведення семінарів для викладачів непедагогічних спеціальностей, активна взаємодія 3 університетськими виданнями (як наукової, так і популярної спрямованості), специфічна організація роботи зі стендом кафедри (крім інформації для студентів, він повинен містити й інформацію для викладачів), сайтом, кафедральними сторінками у соцмережах.

\section{5. Формування і розвиток педагогічного потенціалу магістрантів, які навчаються за двоступеневою програмою}

Третій, лінійний, тип підготовки магістрантів стосується так званої педагогічної магістратури, яка є логічним завершенням одного напряму підготовки - фахівця педагогічних спеціальностей на етапах «бакалаврат-магістратура». Підготовка професіоналів, яким у документах про вищу освіту як кваліфікацію буде вказано «вчитель / вихователь...», визначається цілою низкою об'єктивних та суб'єктивних чинників, серед яких вагоме місце посідає педагогічний потенціал. Причому варто взяти до уваги педагогічний потенціал і науково-педагогічних працівників, і студентів, які з першого року навчання отримують систематизовані знання, набувають практичного досвіду, формують основні структурні компоненти професійно-педагогічної компетентності. Слід особливо відзначити, що лише цей тип підготовки передбачає таку специфіку, як «лабораторне навчання», оскільки їх навчальний досвід грунтується, в тому числі, на безпосередньому спостереженні поведінки / життя у професії, що здійснюється в умовах плинного освітнього процесу, коли викладач-педагог взаємодіє зі студентом-педагогом. Внаслідок цього виникають специфічні віртуальні умови «навчальної лабораторії», за яких значна кількість професійних елементів достатньо суворо регламентується саме обставинами взаємодії «педагог-педагог».

Досить часто педагогічний потенціал поєднують із творчим, інноваційним, i, в контексті цього викладу, ми підтримуємо наукові розвідки цього напряму, які вказують на те, що зростанню професіоналізму вчителя, удосконаленню його як професіонала сприяє саме сформований творчий, інноваційний потенціал. Ступінь його розвиненості обумовлює характер педагогічної взаємодії «педагог-студенти» і забезпечує перетворювальні процеси в особистісних структурах обох сторін. Формування творчого потенціалу майбутнього вчителя / 
вихователя / викладача відбувається впродовж усього періоду професійної підготовки студентів педагогічних спеціальностей, здійснюється як під час аудиторних занять (лекції, семінарсько-практичні заняття), так і в позаавдиторній діяльності - у процесі проходження різних видів педагогічної практики. Аналіз навчальних планів підготовки фахівців галузі знань - 01 «Освіта / Педагогіка», спеціальностей 012 «Дошкільна освіта» та 013 «Початкова освіта», дає можливість констатувати, що формування основ педагогічного потенціалу майбутнього фахівця освіти починається з першого курсу навчання і триває упродовж усього періоду навчання.

Варто зазначити, що вагомою основою для формування потенціалу виступає мотиваційний компонент, який визначається критерієм свідомого вибору професії студентами. Особливо актуальним цей компонент стає саме на етапі магістратури, оскільки, по-перше, навчання за магістерською програмою не є обов'язковою умовою працевлаштування за фахом, отже вибір на користь магістратури це зрілий вибір випускником бакалаврату з педагогіки саме педагогічної спеціальності. По-друге, вступна селекційна діяльність фахівців 3 напряму «Освіта / Педагогіка» дозволяє мотивовано провести відбір абітурієнтів. На цьому етапі, крім мотиваційного, дієвим є також чинник, що передбачає ухвалення аргументованого професійного рішення (наприклад щодо претендентів із вадами мовлення).

Освітня парадигма як сукупність прийнятих науковим педагогічним співтовариством теоретичних, методологічних та інших установок на кожному етапі розвитку педагогіки визначає певну модель (стандарт) при розв'язанні педагогічних проблем підготовки фахівців у галузі освіти. Аналіз змісту освітніх програм підготовки фахівців означених спеціальностей (Львівський національний університет імені Івана Франка) дає змогу виокремити деякі тенденції формування та розвитку педагогічного потенціалу студентів в умовах педагогічної підготовки:

- наступність та систематичність (наявність навчальних дисциплін - «Вступ до спеціальності з основами педагогіки», «Дидактика та педагогічні технології», сукупність різних методик, що відображає специфіку підготовки вчителя початкових класів / вихователя закладу дошкільної освіти); 


\section{Pedagogical potential for professional preparation of masters}

- наскрізна практична підготовка (педагогічна практика починається з 2-го року навчання і, зростаючи у тривалості та складності виконання завдань, закінчується виробничою (переддипломною);

- послідовність та цілеспрямованість (магістерська програма підготовки фахівців є логічним продовженням навчання студентів освітнього рівня «бакалавр»);

- науковий зміст професійно-педагогічної підготовки (професійно зорієнтовані завдання науково-дослідницької, науково-пошукової діяльності студентів освітніх рівнів «бакалавр» та «магістр») [12].

Рівень підготовки фахівців освіти значною мірою визначається якістю навчальних планів, змістом освітніх програм та їх відповідністю вимогам сучасного розвитку суспільства. Як зазначають дослідники, важливе значення мають традиції, що сформувалися в конкретному закладі вищої освіти (рис. 1). Для оптимізації планування освітнього процесу використовуються структурно-логічні схеми і мережеві графіки окремих дисциплін всього курсу навчання, акцентується увага на зміні професійних функцій викладача. Це дає можливість виявляти, аналізувати та впорядковувати зв'язки між окремим дисциплінами освітньої програми, а також... між різноманітними елементами освітнього процесу [18, с. 47-48].

Результатом планування стають розклади занять, де враховуються різносторонні аспекти: методи викладання відповідно до логіки навчальної дисципліни та психофізіологічних можливостей студента; організаційні та індивідуальні критерії, що враховують необхідність самостійної роботи студентів. Вирішальне значення в засвоєнні студентами складного змісту освіти, реалізації сучасних принципів організації освітнього процесу безпосередньо відводиться взаємозалежній і взаємообумовленій діяльності викладачів і студентів. Тому в системі професійно-педагогічної підготовки магістрантів особливої уваги потребує розв'язання проблем удосконалення форм та методів роботи як студентів, так і викладачів. У цьому контексті (щодо лінійного типу підготовки) набирає вагомості кафедральний науково-методичний семінар, завдання якого набувають масштабності саме в царині обговорення та осмислення сутності педагогічної діяльності в посткласичній методології викладання.

Дидактичний цикл в сучасній вищій школі інтегрує традиційні, що виправдали себе в довготривалій практиці, принципи і прийоми 
викладання, з новітніми методами організації обміну та циркулювання науково-професійної інформації. I хоч система організаційних форм навчання передбачає чітку регламентацію співвідношення, обсягу та послідовності різноманітних видів і форм навчальної роботи (більш притаманно традиційній, класичній, парадигмі), проте їх внутрішня структурна організація стає більш пластичною.

Провідною формою в дидактичному циклі закладів вищої освіти більшості країн є лекція. Співвідносно до процесу засвоєння знань вона носить забезпечуючий характер, але, як найбільш гнучка форма навчання, здатна компенсувати відоме відставання в оновленні навчальної інформації, властиве підручникам та деяким іншим видам допомоги, і таким чином активізувати пізнавальну діяльність та творчі інтереси студентів [11, с. 34].

Специфіка педагогічної освіти / професійно-педагогічної підготовки магістра визначається підвищеними, більш того - зростаючими, соціальними вимогами і до професійної діяльності, і до особистості викладача, вчителя, вихователя як суб'єкта педагогічної діяльності, взаємодії в освітньому процесі. Саме тому педагогічна освіта покликана вирішувати два комплекси взаємопов'язаних завдань: по-перше, сприяти соціально цінному розвитку особистості майбутнього педагога (його фундаментальної загальнокультурної підготовки, моральної та громадянської зрілості, що роблять його справжнім наставником наступних поколінь) i, по-друге, сприяти професійному становленню та спеціалізації в обраній галузі педагогічної діяльності. Розвиток особистості педагога закладу вищої освіти - провідна мета, основа й умова ефективної педагогічної освіти саме в магістратурі, тому реалізація завдань професійно-педагогічної підготовки фахівця водночас сприяє розвитку особистості викладача.

Своєрідність педагогічної освіти зумовлена особливими вимогами, що висуваються не тільки до засвоюваних навичок, а й (про що йшлося в аргументації окреслення концепту педагогічного потенціалу) до особистих якостей викладача закладу вищої освіти. Його діяльність передбачає, що, при домінуванні гуманістичної спрямованості і яскравій зорієнтованості на пізнання внутрішнього світу студентів, повинні бути також розвинені інтереси до вивчення світоглядних засад, закономірностей пізнавальної діяльності, акмеологічних аспектів професійного зростання - метапрофесійних чинників. 3 огляду на це, створення 
узагальненої моделі фахівця саме в педагогічній освіті є досить складним завданням, оскільки часто передбачає необхідність суміщення амбівалентних суперечливих процесів.

Зміст педагогічної освіти, отже й проекція педагогічного потенціалу магістра, будується з урахуванням відповідних вимог, які висуваються конкретною спеціальністю чи спеціалізацією (рис. 1). Випускник ЗВО повинен отримати грунтовну (базову) психолого-педагогічну підготовку, а також відповідну спеціальну, властиву певній галузі (бінарний і лінійний типи). Він повинен орієнтуватися в загальнокультурних, філософських, соціально-економічних проблемах, володіти іноземною мовою, а також необхідним практичним досвідом організації роботи зі студентами (стосується всіх типів професійно-педагогічної підготовки в магістратурі).

\section{6. Способи становлення педагогічного потенціалу}

Класифікація типів професійно-педагогічної підготовки є характеристикою організаційного характеру, що обумовлює зовнішні конфігурації, кількісні параметри педагогічного потенціалу. Своєю чергою, ці кількісні параметри залежать і від показника доданої освітньої вартості, що генерується в культурно-освітньому просторі конкретного закладу вищої освіти. Однак, крім зовнішніх, існують також внутрішні аспекти формування/розвитку педагогічного потенціалу в магістратурі. Вони окреслють якісні характеристики, є результатом певного способу методичного розгортання професійно-педагогічної підготовки.

Співвідносно із типами можна вирізнити і відповідні способи формування/становлення педагогічного потенціалу. Перший, точковий, тип забезпечує чи не найбільш загальний, контурний, спосіб, його результативність $є$ достатньо низькою, фактично, йдеться про елементарні фрагментарні уявлення з основ педагогічної діяльності. На нашу думку, цей спосіб можна назвати дифузним. Ступінь можливого наступного розвитку його ефективності залежить від подальшої практики. Значною мірою, результативність цього способу також пов'язана iз впливом відповідної професійної науково-педагогічної школи, що здійснюється завдяки референтному впливу та діє в напрямі саморозвитку й самовдосконалення.

Другий, бінарний, тип забезпечує такий спосіб становлення, що здійснюється шляхом поступового розгортання значного масиву 
професійно-педагогічної інформації. Тобто насамперед йдеться про накопичення відомостей з теорії та практики педагогічної діяльності та можливостей їх розвитку, своєрідного запуску алгоритмів, що в подальшому набуватимуть і масштабності, й інтенсивності. Опираючись на прийняту щодо умовиводів та методів термінологію, вважаємо доречним назвати його дедуктивним, оскільки специфічне розгортання педагогічного потенціалу йде в напрямі від загального до конкретного.

Третій, лінійний, тип є найбільш традиційним. Він опирається на принципи системності (від простого - до складного), наступності (реалізує ступеневість), найменше залежить від сугестивно-адаптивного типу становлення педагога («так робив мій улюблений викладач і я так робитиму»), оскільки є специфічним формуванням педагогічного потенціалу за екологічним принципом, коли магістр педагогічної спеціальності «виростає» в середовищі професії, професійні цінності, виробляючись, водночас інтегруються в особисті. Таким чином формується одразу професійний тип особистості. Низький ступінь залежності від референтної особи пояснюється значною кількістю професійно орієнтованої інформації, отже й здатністю її критично селекціонувати. 3 огляду на застосований вище підхід, такий спосіб доречно означити як індуктивний, бо напрям підготовки рухається від менших елементів до більших, а висновок про загальне випливає з конкретного.

При цьому співвідношення «загальне-конкретне» $є$ динамічним, а структурно-логічні схеми підготовки магістрів, побудовані $з$ дотриманням стереотипних вимог, незабаром міститимуть ще більше спільного, оскільки грунтуватимуться на стандартах вищої освіти, як це вже було до їх відміни.

\section{7. Висновки}

Метою публікації було вивчити фактори формування та розвитку педагогічного потенціалу магістрантів різних освітніх програм підготовки.

Першим завданням, що було вирішене для досягнення поставленої мети було означення поняття педагогічного потенціалу. Найбільше нашим цілям відповідає визначення: «Професійний педагогічний потенціал педагога - це складне динамічне особистісне утворення, що інтегрує сукупність внутрішніх особистих ресурсів людини (психофізіологічні властивості, потреби, здібності, ціннісні орієнтації, 
установки, особисті якості, мотиви, знання, уміння, навички та ін.), які за певних зовнішніх умов можуть проявитися у професійній діяльності у формі усвідомлених професійних дій в ситуаціях професійного вибору» [17, с. 139]. Воно окреслює на лише зовнішні рамки використання концепту «педагогічний потенціал», а й орієнтує на його ресурс і спрямованість.

Результати аналізу освітніх програм підготовки магістрантів за різними напрямами засвідчили існування суттєвих відмінностей між освітніми програмами попри те, що всі випускники магістратури професійно орієнтовані і на викладацьку діяльність. Проведене експрес-дослідження серед викладачів виявило, що диспропорція між викладацькою та предметно-науковою, професійною діяльністю тривало зберігається щодо непедагогічних спеціальностей, відображається в динамічних та змістових характеристиках педагогічного потенціалу як в індивідуальному, так і в його колективному вимірах. На цій основі укладено схему дії чинників на педагогічний потенціал магістрів.

Виявлені в процесі аналізу відмінності між освітніми програмами і специфікою організації підготовки магістрів, що впливають на становлення і розвиток їх педагогічного потенціалу, дозволили типологізувати професійно-педагогічну підготовку магістрантів. Нами сформовано три типи: точковий, бінарний, лінійний. Кожен із них пов'язаний 3 галуззю знань, спеціальністю, крім того - $з$ освітньою програмою та конкретним закладом вищої освіти.

Завдяки вивченню внутрішніх механізмів, задіяних у формуванні педагогічного потенціалу магістрантів, а також логіки їх професійної підготовки сформульовані способи становлення педагогічного потенціалу відповідно до типу професійно-педагогічної підготовки. Дифузний відповідає точковому типу, дедуктивний - бінарному, індуктивний - лінійному.

Перспективи подальших досліджень бачимо у вивченні та виробленні методичних рекомендацій щодо формування освітніх програм підготовки магістрів не з огляду на швидкоплинні зовнішні соціальноекономічні обставини, а з позицій концентрування уваги на становленні педагогічного потенціалу випускника магістратури як необхідної умови для подальшого саморозвитку, прагнення досягнути професійного акме (зокрема й у викладацькій діяльності), отже - сприятливого грунту для освіти упродовж життя. 


\section{Список літератури:}

1. Боднар А. М. Педагогический потенциал учителя: личностно-гуманистический аспект: дис. ... канд. пед. наук : 13.00.01 / А.М. Боднар. Екатеринбург, 1993. - 194 с.

2. Бужина I. Розвиток педагогічного творчого потенціалу студентів у процесі розв'язання ними комунікативних завдань / I. Бужина // Людинознавчі студіï. - 2014. - Вип. 9. - С. 22-30.

3. Гнидіна О. Мистецько-педагогічний потенціал графіки [Електронний pecypc] / О. Гнидіна. - Режим доступу: https://www.pulib.sk/web/kniznica/ elpub/dokument/Bernatova8/subor/Gnydina.pdf

4. Девятова И.Е. Развитие педагогического потенциала учителя в системе корпоративного обучения / И.Е. Девятова // Научное обеспечение системы повышения квалификации кадров. - 2016. - Вып. 3 (28). - С. 138-146.

5. Дудка Т. Педагогічний потенціал освітнього туризму [Електронний pecypc] / Т. Дудка. - Режим доступу: http://ppko-koippo.edukit.kr.ua/Files/ downloads/pdf

6. Єнигін Д.В. Аналіз понятійного апарату термінологічного концепту «педагогічний потенціал» [Електронний ресурс] / Д.В. Снигін // Современные научные исследования и инновации. - 2012. - № 11. - Режим доступу: http:// web.snauka.ru/issues/2012/11/18147

7. Жалдак М.І. Педагогічний потенціал впровадження дистанційних форм навчання / М.I. Жалдак // Матеріали науково-методичного семінару «Інформаційні технології в навчальному процесі». - Одеса : Вид. ВМВ, 2009. - С. 6-8.

8. Закон України «Про вищу освіту» від 01.07.2014 № 1556-VII [Електронний ресурс]. - Режим доступу : http://vnz.org.ua/zakonodavstvo/111zakon-ukrayiny-provyschu-osvitu?start $=4$

9. Козаков В. А. Вища освіта в Україні та у світі: проблема цілей та їх реалізації / В.А. Козаков // Сучасні системи вищої освіти: порівняння для України: монографія. - К. : «Академія», 1997. - С. 60-82.

10. Концепція розвитку педагогічної освіти. Проект [Електронний документ] - Режим доступу: https://mon.gov.ua/ua/news/mon-proponuye-dogromadskogo-obgovorennya-proekt-koncepciyi-rozvitku-pedagogichnoyi-osviti

11. Мачинська Н.I. Сучасні форми організації навчального процесу у вищій школі: навчально-методичний посібник / H.І. Мачинська, С.С. Стельмах. Львів: Львівський державний університет внутрішніх справ, 2012. - 180 с.

12. Навчальні плани та програми курсів у галузі знань «Освіта/Педагогіка» впорядковані з урахуванням спеціальності та спеціалізацій [Електронний pecypc]. - Режим доступу: http://pedagogy.lnu.edu.ua/academics/bachelor

13. Наход С. Педагогічний потенціал інтерактивних технологій навчання / С. Наход // Науковий вісник Мелітопольського державного педагогічного університету. Серія «Педагогіка». - 2014. - № 2 (13). - С. 360-365.

14. Освітньо-професійна програма підготовки бакалавра галузі знань 0305 - Економіка і підприємництво» / Колектив авт. під загал. керівн. А.Ф. Павленка. - К.: КНЕУ імені Вадима Гетьмана, 2010. - 128 с.

15. Педагогічний потенціал ісламу [Електронний ресурс]. - Режим доступу: http://islam.in.ua/ua/istoriya/pedagogichniy-potencial-islamu 


\section{Pedagogical potential for professional preparation of masters}

16. Перець О.С. Педагогічний потенціал традиційного кобзарського репертуару / О.С. Перець // Актуальні питання мистецької педагогіки. - 2015. Вип. 4. - С. 84-89.

17. Рассказов Ф.Д. Профессиональный потенциал педагога как педагогическая категория / Ф.Д. Рассказов, Т.О. Катербарг // Вестник Челябинского государственного университета. - 2013. - № 1. - С. 132-140.

18. Сисоєва С.О. Професійна підготовка викладача-тьютора: теорія і методика: навч.-методичний посібник / С.О. Сисоєва, В.В. Осадчий, К. П. Осадча. Київ; Мелітополь : ТОВ «Видавничий будинок ММД», 2011. - 280 с.

19. Сирцова О. Формування професійно-творчого потенціалу як одна 3 ключових проблем підготовки майбутнього вчителя початкових класів [Електронний ресурс]. - Режим доступу: http://oldconf.neasmo.org.ua/node/933

20. Скиба М. Освіта для турбулентного світу. Як жити, навчати і навчатися на вістрі змін і отримувати від цього задоволення [Електронний ресурс] / М. Скиба - Режим доступу: https:/www.slideshare.net/UIFuture/ss-77740455?ref= https://uifuture.org/uk/post/osvita-dla-turbulentnogo-svitu-dopovid-pdf 332

21. Скорик Т. В. Освітньо-виховний потенціал дозвілля: від народних традицій до сучасності [Електронний ресурс] / Т.В. Скорик // Вісник Чернігівського національного педагогічного університету ім. Т.Г. Шевченка. Режим доступу: http://visnyk.chnpu.edu.ua/?wpfb_dl=1007

22. Scott C.L. The future oflearning 3 : What kind of pedagogies for the 21 stcentury?Retrieved from: http://unesdoc.unesco.org/images/0024/002431/243126e.pdf

23. Словник української мови: в 11 томах. - Т. 5. - К. : Наукова думка, 1974. $-840 \mathrm{c}$.

24. Смолінська О.Є. Теоретико-методологічні засади організації культурно-освітнього простору педагогічних університетів України: дис. ... доктора пед. наук : 13.00.01 / О.С. Смолінська. - Дрогобич, 2015. - 598 с.

25. Стиркіна Ю. Педагогічний потенціал ілюстрацій у процесі вивчення англійської мови майбутніми учителями / Ю. Стиркіна // Естетика і етика педагогічної дії. - 2016. - Вип. 14. - С. 31-40.

26. Тіняков А. Психолого-педагогічний потенціал фізичної культури i спорту у вихованні навичок лідерства студентів вищих навчальних закладів / А. Тіняков // Теорія і практика управління соціальними системами: філософія, психологія, педагогіка, соціологія. - 2016. - № 3. - С. 23-32.

27. Топчій О.В. Педагогічний потенціал професійної діяльності працівників прокуратури [Електронний ресурс]. - Режим доступу: http:/goal-int.org/ pedagogichnij-potencial-profesijnoi-diyalnosti-pracivnikiv-prokuraturi/

\section{References:}

1. Bodnar A. M. (1993) Pedagogicheskii potentsial uchitelia lichnoctno-gumanisticheskii aspekt [Pedagogical potential of the teacher: personal-humanistic aspect] (PhD Thesis), Ekaterinburg.

2. Buzhyna I. (2014) Rozvytok pedahohichnoho tvorchoho potentsialu studentiv u protsesi rozviazannia nymy komunikatyvnykh zavdan [Development of pedagogical creative potential of students in the process of solving their communicative tasks]. Human Studies, vol. 9, pp. 22-30. 


\section{Smolinska Olesia, Machynska Nataliya}

3. Hnydina O. Mystetsko-pedahohichnyi potentsial hrafiky [The artistic and pedagogical potential of graphics]. Retrieved from: https://www.pulib.sk/web/ kniznica/elpub/dokument/Bernatova8/subor/Gnydina.pdf

4. Deviatova I. E. (2016) Razvitie pedagogicheskogo potentsiala uchitelia v sistem korporativnogo obucheniia [Development of the Teachers' Teacher Capacity in the System of Corporate Training]. Nauchnoe obespechenie sistemy povysheniia kvalifikatsii kadrov, vol. 3 (28), pp. 138-146.

5. Dudka T. Pedahohichnyi potentsial osvitnoho turyzmu [Pedagogical potential of educational tourism]. Retrieved from: http://ppko-koippo.edukit.kr.ua/Files/ downloads/pdf

6. Yenyhin D.V. (2012) Analiz poniatiinoho aparatu terminolohichnoho kontseptu "pedahohichnyi potentsial" [The analysis of the conceptual apparatus of the terminological concept "pedagogical potential"]. Sovremennye nauchnye issledovaniia i innovatsii [Modern scientific research and innovations] (electronic journal), vol. 11. Retrieved from: http://web.snauka.ru/issues/2012/11/18147

7. Zhaldak M.I. (2009) Pedahohichnyi potentsial vprovadzhennia dystantsiinykh form navchannia [Pedagogical potential of introduction of distance learning forms]. Proceedings of the Informatsiini tekhnolohii $v$ navchalnomu protsesi (Ukraine, Odesa, May 11-15, 2009), pp. 6-8.

8. Zakon Ukrainy "Pro vyshchu osvitu" vid 01.07.2014 № 1556-VI [Law of Ukraine "On Higher Education” of 01.07.2014 № 1556-VI]. Retrieved from: http://vnz.org.ua/zakonodavstvo/111-zakon-ukrayiny-provyschu-osvitu?start=4

9. Kozakov V. A. (1997) Vyshcha osvita v Ukraini ta u sviti: problema tsilei ta yikh realizatsii [Higher education in Ukraine and in the world: the problem of goals and their implementation] Suchasni systemy vyshchoi osvity: porivniannia dlia Ukrainy [Modern Higher Education Systems: Comparison for Ukraine]. Kyiv: Academia, pp. 60-82.

10. Kontseptsiia rozvytku pedahohichnoi osvity. Proekt (2014) [Concept of development of pedagogical education. Project]. Retrieved from: https://mon.gov.ua/ ua/news/mon-proponuye-do-gromadskogo-obgovorennya-proekt-koncepciyi-rozvitku-pedagogichnoyi-osviti

11. Machynska N.I., Stelmakh S.S. (2012) Suchasni formy orhanizatsii navchalnoho protsesu u vyshchii shkoli [Modern forms of organization of educational process in high school]. Lviv: Lviv State University of Internal Affairs (in Ukrainian).

12. Navchalni plany ta prohramy kursiv u haluzi znan "Osvita/Pedahohika" vporiadkovani z urakhuvanniam spetsialnosti ta spetsializatsii [Curricula and programs of courses in the field of knowledge "Education / Pedagogy" are organized taking into account the specialty and specialization]. Retrieved from: http://pedagogy.lnu.edu.ua/academics/bachelor

13. Nakhod S. (2014) Pedahohichnyi potentsial interaktyvnykh tekhnolohii navchannia [The pedagogical potential of interactive learning technologies]. Scientific herald of Melitopol State Pedagogical University. Series "Pedagogy", vol. 2 (13), pp. 360-365.

14. Pavlenko A. (ed.) (2010) Osvitno-profesiina prohrama pidhotovky bakalavra haluzi znan 0305 - Ekonomika i pidpryiemnytstvo" [Educational-professional program of preparation of the bachelor of the field of knowledge 0305 -Economics and business"]. Kyiv: KNEU named after Vadym Hetman. 


\section{Pedagogical potential for professional preparation of masters}

15. Pedahohichnyi potentsial islamu [The pedagogical potential of Islam]. Retrieved from: http://islam.in.ua/ua/istoriya/pedagogichniy-potencial-islamu

16. Perets O.Ie. (2015) Pedahohichnyi potentsial tradytsiinoho kobzarskoho repertuaru [The pedagogical potential of the traditional kobzar repertoire]. Topical issues of artistic pedagogy, vol. 4, pp. 84-89.

17. Rasskazov F. D. (2013) Professionalnyi potentsial pedagoga kak pedagogicheskaia kategoriia [The professional potential of the teacher as a pedagogical category]. Bulletin of the Chelyabinsk State University, vol. 1, pp. 132-140.

18. Sysoieva S.O., Osadchyi V.V., Osadcha K.P. (2011) Profesiina pidhotovka vykladacha-tiutora: teoriia i metodyka [Professional training of teacher-tutor: theory and methodology]. Kyiv, Melitopol: "MMD Publishing House" (in Ukrainian).

19. Syrtsova O. Formuvannia profesiino-tvorchoho potentsialu yak odna z kliuchovykh problem pidhotovky maibutnoho vchytelia pochatkovykh klasiv [Formation of professional-creative potential as one of the key problems of preparing the future teacher of elementary school]. Retrieved from: http://oldconf.neasmo.org.ua/node/933

20. Skyba M. Osvita dlia turbulentnoho svitu. Yak zhyty, navchaty i navchatysia na vistri zmin $i$ otrymuvaty vid tsoho zadovolennia [Education for turbulent world. How to live, teach and learn on the verge of change and get pleasure from it]. Retrieved from: https://www.slideshare.net/UIFuture/ss-77740455?ref= https://uifuture.org/uk/post/osvita-dla-turbulentnogo-svitu-dopovid-pdf_332

21. Skoryk T. V. Osvitno-vykhovnyi potentsial dozvillia: vid narodnykh tradytsii do suchasnosti [Educational potential of leisure: from folk traditions to the present]. Retrieved from: http://visnyk.chnpu.edu.ua/?wpfb_dl=1007

22. Scott C.L. The future of learning 3: What kind of pedagogies for the 21 st century? - Retrieved from: http://unesdoc.unesco.org/images/0024/002431/243126e.pdf

23. Slovnyk ukrainskoi movy: v 11 tomakh (1974) [Dictionary of the Ukrainian language: in 11 volumes]. Kyiv: Scientific thought (in Ukrainian).

24. Smolinska O. Ye. (2015) Teoretyko-metodolohichni zasady orhanizatsii kulturno-osvitnoho prostoru pedahohichnykh universytetiv Ukrainy [Theoretical and methodological foundations of the organization of cultural and educational space of the pedagogical universities of Ukraine] (Doctoral dissertation), Drohobych: Drohobych Ivan Franko State Pedagogical University.

25. Styrkina Yu. (2016) Pedahohichnyi potentsial iliustratsii u protsesi vyvchennia anhliiskoi movy maibutnimy uchyteliamy [Pedagogical Potential of Illustrations in the Process of Learning English by Future Teachers]. Aesthetics and ethics of pedagogical action, vol. 13, pp. 31-40.

26. Tiniakov A. (2016) Psykholoho-pedahohichnyi potentsial fizychnoi kultury i sportu u vykhovanni navychok liderstva studentiv vyshchykh navchalnykh zakladiv [Psychological-pedagogical potential of physical culture and sport in upbringing of leadership skills of students of higher educational institutions]. Theory and practice of social systems management: philosophy, psychology, pedagogy, sociology, vol. 3, pp. 23-32.

27. Topchii O.V. Pedahohichnyi potentsial profesiinoi diialnosti pratsivnykiv prokuratury [Pedagogical potential of professional activity of prosecutor's staff]. Retrieved from: http://goal-int.org/pedagogichnij-potencial-profesijnoi-diyalnosti-pracivnikiv-prokuraturi/ 